\title{
Klasifikasi Berita Clickbait Menggunakan K-Nearest Neighbor (KNN)
}

\author{
Riska Sagita ${ }^{1}$, Ultach Enri ${ }^{2}$, Aji Primajaya ${ }^{3}$ \\ Teknik Informatika, Universitas Singaperbangsa Karawang \\ Jl. HS. Ronggo Waluyo, Telukjambe Timur, Karawang, Jawa Barat, Indonesia - 41361 \\ E-mail: 'riskasagita1999@gmail.com, ${ }^{2}$ ultach@staff.unsika.ac.id, \\ 3aji.primajaya@staff.unsika.ac.id
}

Diterima: 24 Juni 2020; Direvisi: 14 Oktober 2020; Disetujui: 30 Oktober 2020

\begin{abstract}
Abstrak
Clickbait menjadi salah satu cara untuk mencari pendapatan dengan meningkatkan traffic pembaca dan pengunjung. Praktik clickbait ini memberikan pengaruh besar terhadap penyedia situs berita karena rasa keingintahuan dari para pembaca serta sulitnya para pembaca memilih berita clickbait atau bukan clickbait. Praktik clickbait ini sendiri sangat di andalkan oleh penyedia situs berita yang kerap menggunakan judul-judul yang menjebak untuk menarik para pembaca. Untuk mendapatkan hasil berita clckbait atau bukan clickbait digunakanlah K-Nearest Neighbors (K-NN) dimana waktu proses pada KKN lebih cepat dari pada waktu proses yang lainnya. Dari hasil penelitian yang dilakukan untuk pengklasifikasian berita clickbait, didapatkan hasil terbaik pada jumlah $k=11$ dengan menggunakan skenario 1 pada pembagian data dengan jumlah data sebanyak 800 data latih dan 200 data uji yang menghasilkan akurasi sebesar $71 \%$, Precision 72\%, dan Recall 71\%. Hal ini menunjukan bahwa klasifikasi berita clickbait dapat di klasifikasikan menggunakan K-Nearest Neighbor.
\end{abstract}

Kata kunci: klasifikasi, text mining, clickbait, k-nearest neighbor

\begin{abstract}
Clickbait is a way to generate income by increasing traffic to readers and visitors. This clickbait practice has a major influence on news site providers because of the curiosity of the readers and the difficulty of readers choosing clickbait or non-clickbait news. The clickbait practice itself is heavily relied on by news site providers who often use tricky titles to attract readers. K-Nearest Neighbors (K-NN) is used to get clckbait or non-clickbait news results, where the processing time for KKN is faster than the other processing times. From the results of research conducted for the classification of clickbait news, the best results were obtained at the number $k=11$ by using scenario 1 on data sharing with 800 training data and 200 test data which resulted in an accuracy of $71 \%, 72 \%$ Precision, and 71 Recall. \%. This shows that the classification of clickbait news can be classified using K-Nearest Neighbor.
\end{abstract}

Keywords: classification, text mining, clickbait, $k$-nearest neighbor

\section{PENDAHULUAN}

Internet adalah salah satu teknologi informasi yang sangat diminati oleh banyak kalangan, karena internet telah menyentuh berbagai aspek kebudayaan manusia mulai dari gaya hidup, pendidikan, penelitian hingga ke dunia bisnis. Salah satu manfaat dari internet adalah sebagai penyedia informasi yang cepat dan fleksibel, namun terkadang informasi yang diberikan tidak 
sesuai dengan judul artikel di media elektonik. Judul yang menjebak (Clickbait) merupakan modus media online untuk meningkatkan traffic pengunjung [1]

Clickbait menjadi salah satu cara untuk mencari pendapatan dengan meningkatkan traffic pembaca dan pengunjung. Semakin banyak pengunjung situs, semakin banyak pula kemungkinan untuk mendapatkan pendapatan dari situs tersebut. Faktor pendorong maraknya clickbait di media online adalah persaingan yang semakin ketat antar media untuk mendapatkan pembaca [2] dan pendapatan yang melimpah pada viewer, iklan, memberikan keuntungan berupa materil walaupun pada dasarnya antara judul dan isi tidak memiliki maksud yang sama atau judul yang bombastis tersebut hanya dijelaskan secara singkat atau tidak utuh [3]

Praktik clickbait yang marak terjadi membuat para pembaca kesulitan untuk memilih berita clickbait atau bukan clickbait karena pada pada dasarnya praktik clickbait ini dijadikan sebagai daya tarik para penyedia situs untuk memancing para pembaca yang penasaran akan judul-judul berita yang di buat oleh penyedia situs sehingga praktik clicbait ini memberikan pengaruh yang sangat besar terhadap penyedia situs.

Berdasarkan praktik clickbait yang marak terjadi saat ini untuk pengklasifikasian clickbait atau bukan clickbait pada berita pengelompokan berita dilakukan dengan teknik text mining. Text Mining dapat didefinisikan penemuan serta ekstrasi pengetahuan yang menarik dari sebuah teks yang bebas maupun tidak struktur dan mencakup segala sesuatu mulai dari pengambilan informasi yaitu pengambilan dokumen atau pengambilan web untuk klasifikasi. Dalam penelitian [4] di dapatkan hasil bahwa KNN mendapatkan nilai akurasi yang lebih tinggi dibandingkan dengan SVM. Pada penelitian [5] didapatkan bahwa waktu proses pada KKN lebih cepat dari pada waktu proses SVM maka dapat di silmpulkan bahwa KNN merupakan algoritma yang terbaik. Dari penjelasan yang sudah dipaparkan sebelumnya dapat di lihat menggunakan clickbait pada judul berita memberikan pengaruh besar terhadap situs berita. Tetapi untuk para pembaca hal itu sangat membuat para pembaca resah karena para pembaca tidak dapat membedakan berita clickbait atau bukan clickbait.

Pada penelitian ini menggunakan metode text mining dimana pada metode text mining, dengan 3 skenario untuk pembagian dan algoritma K-Nearest Neighbor ini diharapkan dapat membantu pembaca atau pengunjung situs dalam memilih berita clickbait atau bukan clickbait.

\section{METODOLOGI PENELITIAN}

Metode yang digunakan pada penelitian ini adalah metode text mining, dimana metode ini terdapat beberapa proses diantaranya adalah, 1) data Selection, 2) pre-processing, 3) tranformation, 4) data mining, dan 5) evaluation, berikut alur penelitian pada gambar 1.

\subsection{Data Selection}

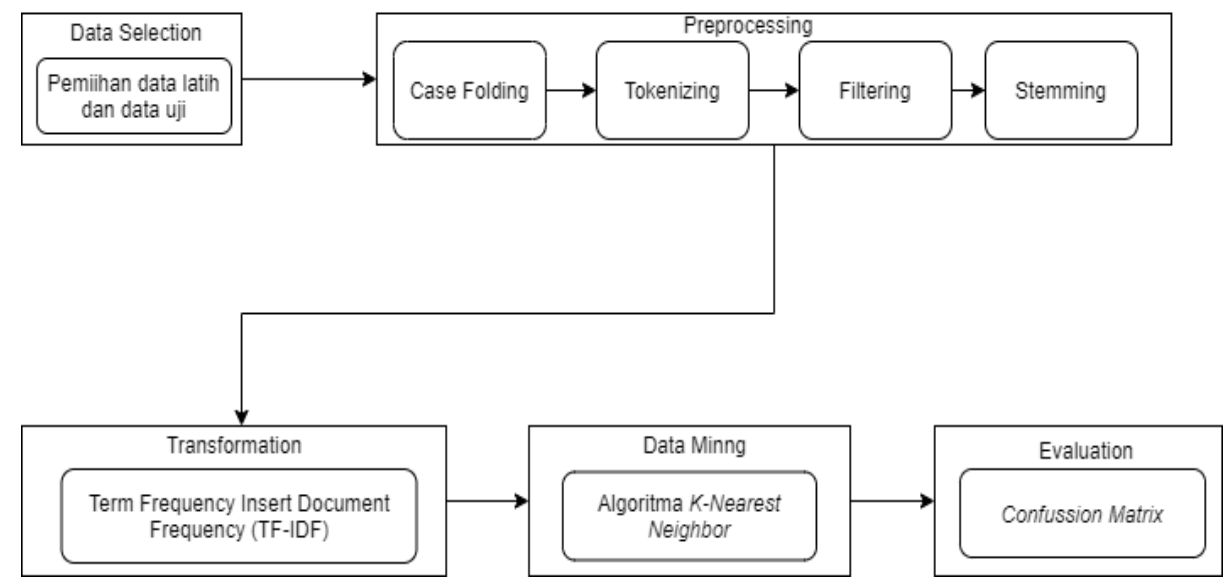

Gambar 1. Alur penelitian 
Pada tahap ini merupakan tahap persiapan dan pemilihan data. Pemilihan data dilakukan dengan mengumpulkan 1000 berita, artikel berita yang akan menjadi data training dan data testing didapat dari situs berita dengan data berita terbit pada bulan januari 2020. Artikel berita yang telah dikumpulkan akan di kelompokkan dan dilabeli secara manual sesuai dengan kategorinya masing-masing yakni clickbait dan bukan clickbait. Pembagian data digunakan 3 skenario pembagian antara data training berbanding dengan data testing yaitu, 80\%:20\%, 50\%:50\%, 20\%:80\%. Dari 3 skenario pembagian data bertujuan untuk mendapatkan nilai performa sistem jika jumlah data training lebih banyak dari data testing, jumlah data training sama dengan jumlah data testing dan jika jumlah data training lebih sedikit dibandingkan dengan data testing.[6]

\subsection{Pre-processing}

Pada tahap preprocessing terdapat bebeapa tahapa untuk mentransformasikan data ke dalam bentuk representasi format data lain, berikut tahapan-tahapan pada pre-processing:

1. Case folding adalah transformasi huruf pada teks, semua huruf diubah menjadi huruf kecil. Karakter huruf yang dihasilkan harus berupa 'a' sampai karakter huruf ' $z$ '. Selain karakter huruf tersebut harus dianulir [7].

2. Tokenizing merupakan proses untuk memisahkan kata-kata dari sebuah kalimat atau memutus urutan string menjadi potongan-potongan seperti kata-kata berdasarkan tiap kata yang menyusunnya [8].

3. Stopwords Removal atau Filtering, stoplist atau stopword adalah proses menghilangkan kata-kata yang tidak penting dengan pendekatan bag-of-words. Hasil dari stoplist adalah wordlist yang berisi kata penting. [9].

4. Stemming, merupakan proses pemetaan dan penguraian berbagai bentuk (variants) dari suatu kata menjadi bentuk kata dasarnya (stem) [10].

\subsection{Tranformation}

Pada tahap ini metode dipresentasikan dalam dokumen yang berisi bobot kata. Bobot tersebut menyatakan kepentingan atau kontribusi kata terhadap suatu dokumen dan kumpulan dokumen. Tahap pembobotan kata pada dokumen menggunakan metode TF-IDF. Metode TFIDF ini menggabungkan dua konsep yaitu frekuensi kemunculan sebuah kata di dalam sebuah dokumen dan inverse frekuensi dokumen yang mengandung kata tersebut [11].

Rumus dalam menentukan pembobot dengan TF-IDF seperti pada persamaan (1):

$$
I D F(\text { Word })=\log \frac{t d}{t f}
$$

IDF (word) adalah nilai IDF dari setiap kata yang akan di cari, $t d$ adalah jumlah keseluruhan dokumen yang ada, $d f$ adalah jumlah kemuculan kata pada semua dokumen.

\subsection{Data Mining}

Pada tahap ini menggunakan K-Nearest Neighbor (KNN), Dalam pengklasifikasian terdapat 2 proses yang dilakukan yakni proses training dan proses testing. Proses pengklasifikasian dilakukan dengan menentukan nilai $\mathrm{K}$ terlebih dahulu, menghitung kuadrat jarak euclid(query instance) masing-masing objek terhadap training data yang diberikan, lalu mengumpulkan label class Y (klasifikasi Nearest Neighbor) dengan persamaan (2).

$$
\begin{gathered}
\mathrm{D}\left(\mathrm{x}_{i}, \mathrm{y}_{i}\right)=\sqrt{\sum_{i=1}^{n}\left(\mathrm{x}_{i}, \mathrm{y}_{i}\right)^{2}} \\
\text { Keterangan: } \mathrm{Xi}=\text { data training } \\
\mathrm{Yi}=\text { data testing } \\
\mathrm{D}(\mathrm{xi},, \text { yi })=\text { jarak } \\
\mathrm{i}=\text { variabel data } \\
\mathrm{n}=\text { Dimensi data }
\end{gathered}
$$

\subsection{Evaluation}

Pada tahap terakhir ini dilakukan evaluasi nilai akurasi, precision dan recall yang 
merupakan tahapan dalam penelitian dengan tujuan untuk mengetahui pengaruh model yang dihasilkan dari pengklasifikasian yang telah dilakukan. Pada penelitian ini hasil yang disajikan berupa grafik dengan metode validasi yang digunakan adalah Confusion matrix yang memberikan keputusan berdasarkan hasil dari training dan testing serta memberikan penilaian performansi klasifikasi berdasarkan data dengan benar atau salah.

Tabel 1. Confusion matrix

\begin{tabular}{|c|c|c|}
\hline \multirow{2}{*}{ Classification } & \multicolumn{2}{|c|}{ Predicted Class } \\
\cline { 2 - 3 } & Class $=$ Yes & Class $=$ No \\
\hline Class $=$ Yes & $\mathrm{a}($ True Positive $-\mathrm{TP})$ & $\mathrm{b}($ False Negative $-\mathrm{FN})$ \\
\hline Class $=$ No & $\mathrm{c}($ False Positive $-\mathrm{FP})$ & $\mathrm{d}($ True Negative $-\mathrm{TN})$ \\
\hline
\end{tabular}

Terdapat beberapa cara untuk mengukur performa, beberapa cara yang sering digunakan adalah dengan menghitung akurasi, recall, dan precission[8].

$$
\begin{aligned}
& \text { Akurasi }=\frac{T P+T N}{T p+T N+F P+F N} \\
& \text { Precision }=\frac{T P}{T p+F P} \\
& \text { Recall }=\frac{T P}{T P+F N}
\end{aligned}
$$

Evaluasi dan validasi hasil dihitung dengan menggunakan rumus accuracy pada persamaan (3), precision pada persamaan (4), sensitifity pada persamaan (5), dan spesificity. Nilai akurasi dinyatakan dalam persentase. Jika akurasi mencapai angka 100\%, hal tersebut berarti bahwa semua kasus yang diprediksi diklasifikasikan seluruhnya sengan benar [12].

\section{HASIL DAN DISKUSI}

Bagian ini memaparkan hasil dari proses klasifikasi berita clickbait. Proses dimulai dengan membagi data berita yang dikumpulkan pada situs berita dengan data terbit pada bulan januari 2020 ke dalam data latih dan data uji. Kedua, melaksanakan setiap langkah preprocessing, kemudian menghitung bobot dengan TF-IDF dan implementasi algoritma $K$-Nearest Neighbor $(K N N)$. Terakhir melakukan evaluasi dan uji validasi dengan Confusion Matrix

\subsection{Data Selection}

Pada penelitian ini data berita yang digunakan adalah 1000 berita yang telah dilakukan labelling dengan 2 kategori yaitu kategori clickbait dan bukan clickbait. Data berita dilakukan pelabelan dengan cara manual tiap berita berita diberi label clickbait (C) atau bukan clicbait (BC) yang ditampilkan pada gambar 2. Berita yang dilabeli clickbait (C) mengandung kata yang bersifat hiperbola pada judul dan ketidaksesuaian isi berita dengan judul, sedangkan berita yang dilabeli bukan clickbait (BC) berita yang tidak mengandung kata hiberbola dan berita sudah sesuai antara judul dan isi berita. Data yang digunakan sudah di periksa kembali dengan membaca isi berita, berita yang sesuai dengan judul atau yang tidak sesuai dengan judul, berita yang tidak sesuailah yang nantinya akan mendapatkan label dengan kategori clickbait. Proses pelabelan memakan waktu 2 bulan, mulai dari tanggal 16 Maret sampai 16 Mei 2020.

Setalah dilakukan pelabelan pembagian data training dan data testing berdasarkan penelitian [6] dilakukan dengan 3 skenario rasio yaitu 80\%:20\%, 50\%:50\%, dan 20\%:80\% untuk melihat performa dari sistem jika jumlah data training lebih banyak dari data teting dan data training sama dengan data testing begitupun sebaliknya . Data input pada penelitian menggunakan format ekstensi xlsx. 


\begin{tabular}{|c|c|}
\hline Judul & Kategori \\
\hline Yasonna Copot Dirjen Imigrasi Ronny Sompie Terkait Kasus Harun Masiku, Ini Respons KPK & C \\
\hline 2 Bukti Ditemukan, Polisi Bekuk Pegawai Kedai Kopi Lempar Susu ke Driver Ojol sampai Berdarah & $B C$ \\
\hline 2 Orang Kembali Dilaporkan Terinfeksi Virus Corona di Thailand & $\mathrm{BC}$ \\
\hline 2 Pengasuh PAUD Jadi Tersangka Kasus Mayat Balita Tanpa Kepala, Ayah Korban_Kami Tak Terlalu Senang & $B C$ \\
\hline 3 Hari Cari Lutfi Alfiandi, Ibunda Ungkap Telpon Terakhir Saat Anak Ditangkap_Ampun Ampun ke Polisi & $B C$ \\
\hline 3 Minuman Tradisional di Bandung yang Bisa Menghangatkan Tubuh Saat Musim Hujan & BC \\
\hline 3 Restoran Legendaris di Jakarta Pusat Sejak 1960-an, Cocok Bersantap Bersama Keluarga & BC \\
\hline 3 Zodiak Pendiam yang Tidak Suka Membuka Obrolan dengan Orang Baru, Kamu Termasuk_ & $B C$ \\
\hline 4 Cara Mudah untuk Mengurangi Kebiasaan Menunda Pekerjaan, Coba Yuk! & $B C$ \\
\hline 4 Fakta Jelang Hasil Autopsi Lina Diumumkan_Ada Video CCTV Sebelum Lina Meninggal, Kekecewaan Teddy & $B C$ \\
\hline 5 Fakta Pasukan Quds, Pasukan Elit Iran yang Dipimpin Mayjen Qasem Soleimani, Pahlawan atau Teroris & $\mathrm{C}$ \\
\hline 5 Fakta Penangkapan Kurir Narkoba di Serpong, dari Kode 'Rahasia' hingga Sabu Senilai 864 Miliar & $\mathrm{BC}$ \\
\hline 5 FAKTA TERBARU Kasus Medina Zein_Akui Tak Beri ASI pada Anaknya, hingga Dukungan Zaskia Sungkar & $B C$ \\
\hline 5 Hantu Populer yang Dikenal Masyarakat Indonesia, dari Tuyul hingga Kuntilanak & $B C$ \\
\hline 5 Wanita Cantik 'Korban' Valentino Rosși, Ada Mantan Istri Musuh Bebuyutannya di Mc & $B C$ \\
\hline
\end{tabular}

Gambar 2. Data berita hasil pelabelan

\subsection{Pre-processing}

Pada tahan pre-procesing terdapat beberapa tahap yang harus dilakukan yaitu tahap case folding, tokening, filtering, dan stemming. Tahapan ini menggunakan bahasa pemrograman Python pada Google Colab dengan memanfaatkan libray Sastrawi dengan hasil pada tabel 2.

1. Case folding, tahap ini data berita dirubah menjadi huruf kecil, menghapus angka, menghapus tanda baca dan menghapus spasi.

2. Tokennizing, tahap ini dilakukan pemecahan kalimat judul berita menjadi kata sehingga setelah tokenizing judul berita terpisah-pisah perkata.

3. Filtering, tahap ini dilakukan penghilangan kata sambung atau kata yang tidak penting dengan menggunakan teknik removes stopword. Pada penelitian library yang digunakan untuk teknik removes stopword adalah library Sastrawi.

4. Stemming, Pada tahap ini mengubah kata imbuhan menjadi kata dasar. proses ini juga menggunakan library yang sama yaitu library Sastrawi

Tabel 2. Contoh proses pre-processing

\begin{tabular}{ll}
\hline Data & $\begin{array}{l}\text { 3 Zodiak Pendiam yang Tidak Suka Membuka Obrolan dengan Orang Baru, } \\
\text { Kamu Termasuk } \\
\text { Case Folding } \\
\text { zodiak pendiam yang tidak suka membuka obrolan dengan orang baru kamu } \\
\text { termasuk }\end{array}$ \\
Tokennizing & $\begin{array}{l}\text { zodiac, pendiam, yang, tidak, suka, membuka, obrolan, dengan, orang, baru, } \\
\text { kamu, termasuk }\end{array}$ \\
Filtering & $\begin{array}{l}\text { zodiac, pendiam, suka, membuka, obrolan, orang, baru, kamu, termasuk } \\
\text { Ztemming }\end{array}$ \\
\hline
\end{tabular}

\subsection{Transformation}

Pada tahap ini dilakukan proses Term Frequency dilakukan untuk pembobotan kata dengan menggunakan TF-IDF. Pemberian bobot nilai pada tiap kata akan dihitung probabilitasnya, perhitungan pembobotan kata dilakukan dengan cara menentukan nilai Term Frequency (TF) seperti pada gambar 3. 


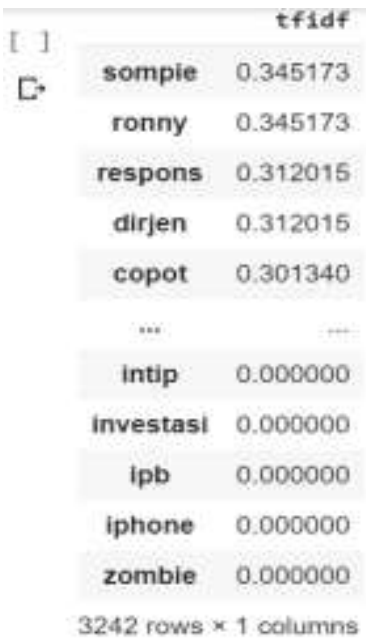

Gambar 3 Hasil Pembobotan Kata TF-IDF

\subsection{Data Mining}

Pada tahap ini dilakukan pemodelan dengan K-Nearest Neighbor (KNN). Pada pemodelan ini pembagian data training dan data testing dibagi menjadi 3 skenario yang titampilkan pada tabel 3 yaitu pembagian antara data training berbanding dengan data testing yaitu, 80\%:20\%, 50\%:50\%, 20\%:80\%.

Tabel 3 Pembagian Data Training dan Testing

\begin{tabular}{ccc}
\hline \multirow{2}{*}{ Skenario 1 } & Data Training (80\%) & Data Testing (20\%) \\
& 800 & 200 \\
Skenario 2 & Data Training (50\%) & Data Testing (50\%) \\
& 500 & 500 \\
Skenario 3 & Data Training (20\%) & Data Testing (80\%) \\
& 200 & 800 \\
\hline
\end{tabular}

Pengujian KNN pada penelitian ini dilakukan pemodelan dengan menggunakan KNearest Neighboar dengan parameter nilai k pada KNN yaitu 1,3,5,7,9,11,13,15 dimana untuk melihat apakah parameter nilai k ini mempengaruhi hasil dari klasifikasi dokumen berita clickbait tersebut. Berikut merupakan hasil dari modek klasifikasi KNN dengan menggunakan data training.

Tabel 4 Tabel Hasil Nilai Akurasi

\begin{tabular}{cccc}
\hline & Skenario 1 & Skenario 2 & Skenario 3 \\
\hline $1-\mathrm{NN}$ & $58 \%$ & $55 \%$ & $57 \%$ \\
$3-\mathrm{NN}$ & $57 \%$ & $54 \%$ & $60 \%$ \\
$5-\mathrm{NN}$ & $66 \%$ & $58 \%$ & $58 \%$ \\
$7-\mathrm{NN}$ & $68 \%$ & $56 \%$ & $59 \%$ \\
$9-\mathrm{NN}$ & $69 \%$ & $59 \%$ & $59 \%$ \\
$11-\mathrm{NN}$ & $71 \%$ & $57 \%$ & $56 \%$ \\
$13-\mathrm{NN}$ & $69 \%$ & $55 \%$ & $56 \%$ \\
$15-\mathrm{NN}$ & $68 \%$ & $56 \%$ & $55 \%$ \\
\hline
\end{tabular}

Berdasarkan tabel 4 dapat dilihat bahwa hasil model KNN untuk nilai akurasi dengan nilai $\mathrm{k}=11$ mendapatkan nilai terbaik pada skenario 1 yang menghasilkan nilai akurasi sebesar $71 \%$. 
Tabel 5 Tabel Hasil Nilai Precision

\begin{tabular}{rccc}
\hline & Skenario 1 & Skenario 2 & Skenario 3 \\
\hline 1-NN & $58 \%$ & $55 \%$ & $57 \%$ \\
3-NN & $57 \%$ & $54 \%$ & $60 \%$ \\
5-NN & $66 \%$ & $58 \%$ & $58 \%$ \\
$7-N N$ & $68 \%$ & $56 \%$ & $59 \%$ \\
9-NN & $69 \%$ & $59 \%$ & $59 \%$ \\
$11-\mathrm{NN}$ & $72 \%$ & $57 \%$ & $56 \%$ \\
$13-\mathrm{NN}$ & $69 \%$ & $55 \%$ & $56 \%$ \\
$15-\mathrm{NN}$ & $68 \%$ & $56 \%$ & $55 \%$ \\
\hline
\end{tabular}

Berdasarkan tabel 5 dapat dilihat bahwa hasil model KNN untuk inlai Precision dengan nilai $\mathrm{k}=11$ mendapatkan nilai terbaik pada skenario 1 yang menghasilkan nilai akurasi sebesar $72 \%$.

Tabel 6 Tabel Hasil Nilai Recall

\begin{tabular}{cccc}
\hline & Skenario 1 & Skenario 2 & Skenario 3 \\
\hline 1-NN & $58 \%$ & $55 \%$ & $57 \%$ \\
3-NN & $57 \%$ & $54 \%$ & $60 \%$ \\
5-NN & $66 \%$ & $58 \%$ & $58 \%$ \\
7-NN & $68 \%$ & $56 \%$ & $59 \%$ \\
9-NN & $69 \%$ & $59 \%$ & $59 \%$ \\
$11-\mathrm{NN}$ & $71 \%$ & $57 \%$ & $56 \%$ \\
$13-\mathrm{NN}$ & $69 \%$ & $55 \%$ & $56 \%$ \\
$15-\mathrm{NN}$ & $68 \%$ & $56 \%$ & $55 \%$ \\
\hline
\end{tabular}

Berdasarkan tabel 6 dapat dilihat bahwa hasil model KNN untuk inlai Recall dengan nilai $\mathrm{k}=11$ mendapatkan nilai terbaik pada skenario 1 yang menghasilkan nilai akurasi sebesar $71 \%$.

\subsection{Evaluation}

Hasil yang diperoleh keseluruhan semua tes yang dilakulukan pemodelan KNN.menghasilkan nilai tingkat akurasi, precision, dan recall. Berikut ini merupakan hasil grafik pemodelan KNN menggunakan 3 skenario.

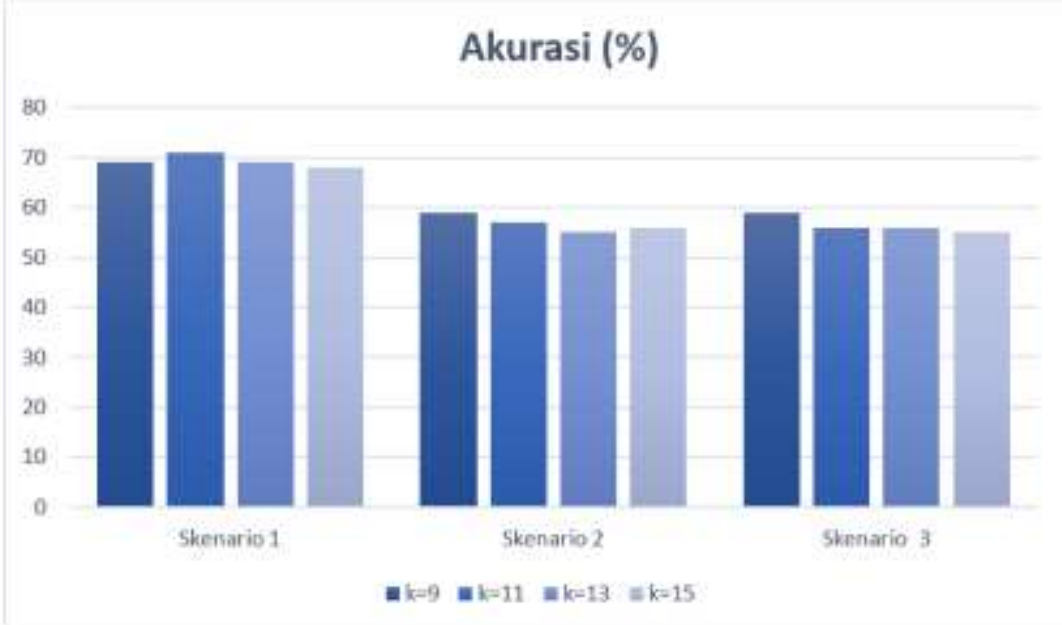

Gambar 4 Grafik Akurasi Pemodelan KNN

Pada gambar 4 menunjukkan perbandingan nilai akurasi dengan skenario pembagian dataset. Dari hasil tersebut menunjukkan bahwa jumlah data training mempengaruhi tingkat 
performa, terlihat pada skenario pembagian dataset $80 \%-20 \%$ dengan nilai $\mathrm{k}=9$ sampai $\mathrm{k}=15$ mendapatkan nilai akurasi tertinggi dengan nilai mencapai $71 \%$ dan pada splitting dataset 20\%:80\% mendapatkan nilai akurasi terendah. Hal ini disebabkan karena semakin banyak data training akan menambah informasi dari karakteristik setiap kelas berita.

\section{KESIMPULAN}

Dari hasil penelitian yang telah dilakukan dapat disimpulkan Pengklasifikasian berita clickbait dilakukan beberapa proses seperti case folding, tekonizing, filtering, stemming, term weight (TF-IDF) dan melakukan pemodelan dengan menggunakan algoritma K-Nearest Neighbor dan melakukan pemilihan nilai $\mathrm{K}$ untuk mendapatkan model terbaik. Rasio perbandingan data latih dan uji pada skenario 1 dengan rasio perbandingan sebesar 80\%:20\% memiliki performa paling tinggi, sehingga dapat disimpulkan bahwa jumlah data latih yang semakin banyak akan menambah ketepatan klasifikasi dikarenakan sistem akan banyak mendapatkan informasi dari data latih. Berdasarkan hasil uji coba parameter pada model pengklasifikasian dengan menggunakan algoritma K-Nearest Neighboar (KNN) menunjukan bahwa model pengklasifikasian terbaik adalah model dengan nilai $\mathrm{k}=11$ pada skenario 1 yang menghasilkan nilai akurasi sebesar $71 \%$, dengan di dapatkannya nilai akurasi terbaik maka dapat diketahui bahwa pengaruh clickbait terhadap tingkat pengunjung pada situs berita sangat berperan sehingga situs berita mendapatkan traffic cukup bagus untuk setiap berita-berita nya

\section{SARAN}

Ada beberapa saran yang perlu diperhatikan untuk dapat melakukan penelitian lebih lanjut agar mendapatkan hasil yang lebih baik lagi. Diantaranya menambahkan jumlah dataset yang digunakan, dengan menambahkan jumlah dataset diharapkan mampu menambah jumlah dan keragaman informasi sehingga dapat menambah informasi dari metode k-nearest neighbors dan meningkatkan performa sistem. Menggunakan model yang beragam serta pemilihan parameter nilai K yang lebih banyak, agar semakin jelas seberapa berpengaruh parameter nilai $\mathrm{K}$ terhadap sistem. Menggunakan algoritma lainya untuk mendapatkan model pengklasifikasian terbaik yang dapat memungkinkan meningkatkan nilai akurasi yang rendah.

\section{DAFTAR PUSTAKA}

[1] A. F. Yavi, "Klasifikasi Artikel Berbahasa Indonesia untuk Mendeteksi Clickbait menggunakan Metode Naïve Bayes," J. Inf. Technol., vol. 06, no. 01, pp. 141-147, 2018.

[2] M. Rizky and M. R. Kertanegara, "Penggunaan Clickbait Headline pada Situs Berita dan Gaya Hidup Muslim Dream . co . id,” Mediat. J. Komun., vol. 11, no. June 2017, pp. 3143, 2018.

[3] Y. Yamlean, "Clickbait Journalism Dan Pelanggaran Etika Jurnalistik (Studi Kasus Pelanggaran Etika Jurnalistik Dalam Praktik Clickbait Pada Media Online Jogja.Tribunnews.Com Periode 1 Maret 2019 - 30 April 2019)," Universitas mercu buana yogyakarta, 2019.

[4] L. A. Utami, "Analisis Sentimen Opini Publik Berita Kebakaran Hutan Melalui Komparasi Algoritma Support Vector Machine Dan K-Nearest Neighbor Berbasis Particle Swarm Optimization,” J. Pilar Nusa Mandiri, vol. 13, no. 1, pp. 103-112, 2017.

[5] S. kartika Lidya, O. S. Sitompul, and S. Efendi, "Sentiment Analysis Pada Teks Bahasa Indonesia Menggunakan Support Vector Machine (Svm) Dan K-Nearest Neighbor (KNn)," Semin. Nas. Teknol. Inf. dan Multimed. 2015, no. maret, pp. 1-8, 2015. 
[6] A. A. Irfa and M. S. Mubarok, "Klasifikasi Topik Berita Berbahasa Indonesia Menggunakan k-Nearest Neighbor," e-Proceeding Eng., vol. 5, no. 2, pp. 3631-3640, 2018.

[7] F. N. Rozi and D. H. Sulistyawati, "Klasifikasi Berita Hoax Pilpres Menggunakan Metode Modified K-Nearest Neighbor Dan Pembobotan Menggunakan Tf-Idf," KONVERGENSI, vol. 15, no. Januari, 2019.

[8] S. Nur and K. Fithriasari, "Klasifikasi Berita Online Menggunakan Metode Support Vector Machine dan K- Nearest," J. Sains dan Seni ITS, vol. 5, no. 2, pp. 2337-3520, 2016.

[9] A. R. Prasetyo, Idriati, and P. P. Adikara, "Klasifikasi Hoax Pada Berita Kesehatan Berbahasa Indonesia Dengan Menggunakan Metode Modified K-Nearest Neighbor," $J$. Pengemb. Teknol. Inf. dan Ilmu Komput., vol. 2, no. 12, pp. 7466-7473, 2018.

[10] Z. U. Siregar, R. R. A. Siregar, and R. Arianto, "Klasifikasi Sentiment Analysis Pada Komentar Peserta Diklat Menggunakan Metode K-Nearest Neighbor," J. Kilat, vol. 8, no. 1, pp. 81-92, 2019.

[11] B. Herwijayanti, D. E. Ratnawati, and L. Muflikhah, "Klasifikasi Berita Online d engan menggunakan Pembobotan TF-IDF dan Cosine Similarity," J. Pengemb. Teknol. Inf. dan Ilmu Komput., vol. 2, no. 1, pp. 306-312, 2018.

[12] A. Khoirunnisa, B. Irawan, and R. M Rumani, "Analisis dan implementasi perbandingan algoritma c.45 dengan naïve bayes untuk prediksi penawaran produk," e-Proceeding Eng., vol. 3, no. 3, pp. 5029-5035, 2016. 